\title{
Impacts of Ecological Restoration and Human Activities on Habitat of Overwintering Migratory Birds in the Wetland of Poyang Lake, Jiangxi Province, China
}

\author{
SUN Chuan-zhun1,2 (D http://orcid.org/oooo-0oo3-2642-4269; e-mail: suncz.11b@igsnrr.ac.cn

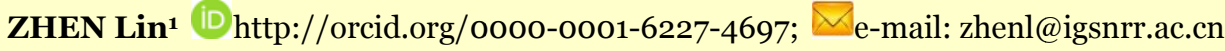 \\ WANG Chao',2 iD http://orcid.org/oooo-0002-2636-6989; e-mail: wangc.12b@igsnrr.ac.cn

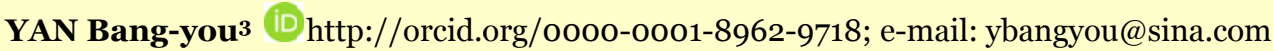 \\ CAO Xiao-chang1,2 (D http://orcid.org/oooo-0oo1-6776-8696; e-mail: caoxiaochang.gg@163.com \\ WU Rui-zi',2 (D)http://orcid.org/oooo-0oo3-2168-2824; e-mail: wuruizioo7@sina.com \\ 1 Institute of Geographic Sciences and Natural Resources Research, Chinese Academy of Sciences, Beijing 10o101, China \\ 2 Graduate University of Chinese Academy of Sciences, Beijing 10oo49, China \\ 3 Office of the Mountain-River-Lake Development Committee of Jiangxi Province, Nanchang 330o46, China
}

Citation: Sun CZ, Zhen L, Wang C, et al. (2015) Impacts of ecological restoration and human activities on habitat of overwintering migratory birds in the wetland of Poyang Lake, Jiangxi Province, China. Journal of Mountain Science 12(5). DOI: $10.1007 / \mathrm{s} 11629-014-3128-8$

(C) Science Press and Institute of Mountain Hazards and Environment, CAS and Springer-Verlag Berlin Heidelberg 2015

\begin{abstract}
Increasing human activities have contributed to global climate change, and thus resulted in a downward trend in the number of species and population sizes of migratory birds. This trend is closely related to a reduction in habitat size and lower habitat quality. The Poyang Lake wetland in China constitutes one of Asia's largest overwintering habitats for migratory birds. Over the past 10 years, restoration projects have improved the habitat ecology of these wetlands. In this study, we assessed the changes in habitat quality for overwintering migratory birds from 2000 to 2012 near two villages in the Poyang Lake wetland using the InVEST model. Average habitat quality for migratory birds has been improved by $18.8 \%$ and $47.7 \%$. Differences in the degrees of habitat improvement can be attributed to differences in the change of habitat size and in the impact of threat sources that resulted from the combined effects of restoration and human activities in these two villages.
\end{abstract}

Received: 1 May 2014

Accepted: 28 September 2014
Keywords: Wetland; Ecological restoration; InVEST model; Migratory bird; Habitat

\section{Introduction}

Favorable bird habitats provide sufficient food resources, suitable breeding sites, and protection from predators and adverse climate, thus ensuring survival and reproduction of the birds (Zhang and Zheng 1999). Habitat quality can directly affect the distribution, population density, reproductive rates, and survival of adult birds (Cody 1985). In the last century, human activities have led to wetland decrease as much as $50 \%$, and the existing wetland is facing degradation to different degrees (Fraser and Keddy 2005), with serious impact on habitat of waterfowl. Habitat improvement is the core problem for waterfowl protection (Weber and Haig 1996; Erwin 2002; Taft et al. 2002). So far, research on the impact of human activities on 
waterfowl habitat has been focused on field studies such as habitat area change, vegetation change, water level fluctuation and engineering construction (eg. Zhao 2002; Bancroft et al. 2002; Kaminski et al. 2006; Wu et al. 2009). There is less research focusing on the impact of habitat quality related to different kinds of human activities. Ecological restoration is one of the most important measures to improve the habitat quality for waterfowl. Most quantitative studies in managed wetlands have been conducted in artificial wetlands, and there has been little in-depth research on how habitat changes affect those that have already been restored (Ma et al. 2010). Moreover, there has been little research on how ecological restoration and other human activities (such as agriculture activities and commuting activities) affect habitat quality of waterfowl.

The Poyang Lake wetland in Jiangxi Province, China is one of the largest overwintering habitats for migratory birds in Asia. Recognizing degradation trends and the importance of this wetland, the Chinese government implemented "returning farmland to lake" (RFL) and "returning farmland to forest" (RFF) ecosystem restoration projects, which began in 1998 and 2000, respectively, leading to positive effects on the ecological environment (Li et al. 2009).

The RFL project was developed to mitigate the problems created by wetland conversion into agricultural uses. In 1998, the Chinese government implemented the RFL project in the Central Yangtze River floodplain to remove existing dikes that excluded water from fields and damaged lakes and surrounding low-lying areas. The Poyang Lake region was one of the most important RFL projects in this floodplain. This project was implemented involving two different patterns: "Double return" pattern involved both the conversion of farmland into wetlands and relocation to higher ground of people who lived near the lake and were would be threatened by the resulting flooding. "Single return" involved only the conversion of farmland into wetlands, without relocating the population. The RFL project created an ecological niche for wetland species by increasing the available habitat and improving conditions for survival and reproduction (Jiang et al. 2005). The RFF project was designed to restore this function in the lands on steep topography which were used for cultivation. This project moved agriculture activities further from waterbird habitat.

In view of the importance of the Poyang Lake wetland, researchers have focused on the lake's biodiversity and particularly on the number of species and population sizes of the water birds that use these wetlands (Barter et al. 2004; Barzen et al. 2009; Kwaiser 2009; Wu et al. 2009). However, useful data is not yet available and unsuitable methods have limited the information to assess the effects of ecological restoration and other human activities on the suitability of the wetlands for overwintering birds.

In this paper, we present our analysis of changes in the habitat quality for overwintering birds based on surveys around two Poyang Lake wetland villages over a 12-year period. First of all, change of habitat area and threat source from that period was analyzed and we used the ecosystem services analysis tool InVEST (Integrated Valuation of Ecosystem Services and Tradeoffs; Tallis et al. 2013) to show that habitat quality for migratory birds was improved around Chenlang (18.8\%) and Yuanlong (47.7\%) villages.

\section{Methods}

\subsection{Study area}

The Poyang Lake wetland is located in northern Jiangxi Province, China, on the southern bank of the middle and lower reaches of the Yangtze River $\left(28^{\circ} 22^{\prime} \mathrm{N}\right.$ to $29^{\circ} 45^{\prime} \mathrm{N}, 115^{\circ} 47^{\prime} \mathrm{E}$ to $117^{\circ} 45^{\prime} \mathrm{E}$; Figure 1). This is the largest freshwater lake in China and serves as the drainage basin for five sub-watersheds. Water levels in the lake vary seasonally (from 9.8 to $15.4 \mathrm{~m}$ within a year; $\mathrm{Li}$ et al. 2008) as a result of water exchange between the Yangtze River and the lake during flooding and dry periods. During the summer, the lake's water surface area decreases from $4000 \mathrm{~km}^{2}$ to $1000 \mathrm{~km}^{2}$ (Shankman and Liang 2003), and by the start of autumn, natural drainage leads to the exposure of large mudflats and independent lakes (Yesou et al. 2009).

These dramatic hydrological changes led to equally dramatic changes in the ecological processes in Poyang Lake and directly affected the characteristics of its different habitats and its rich 


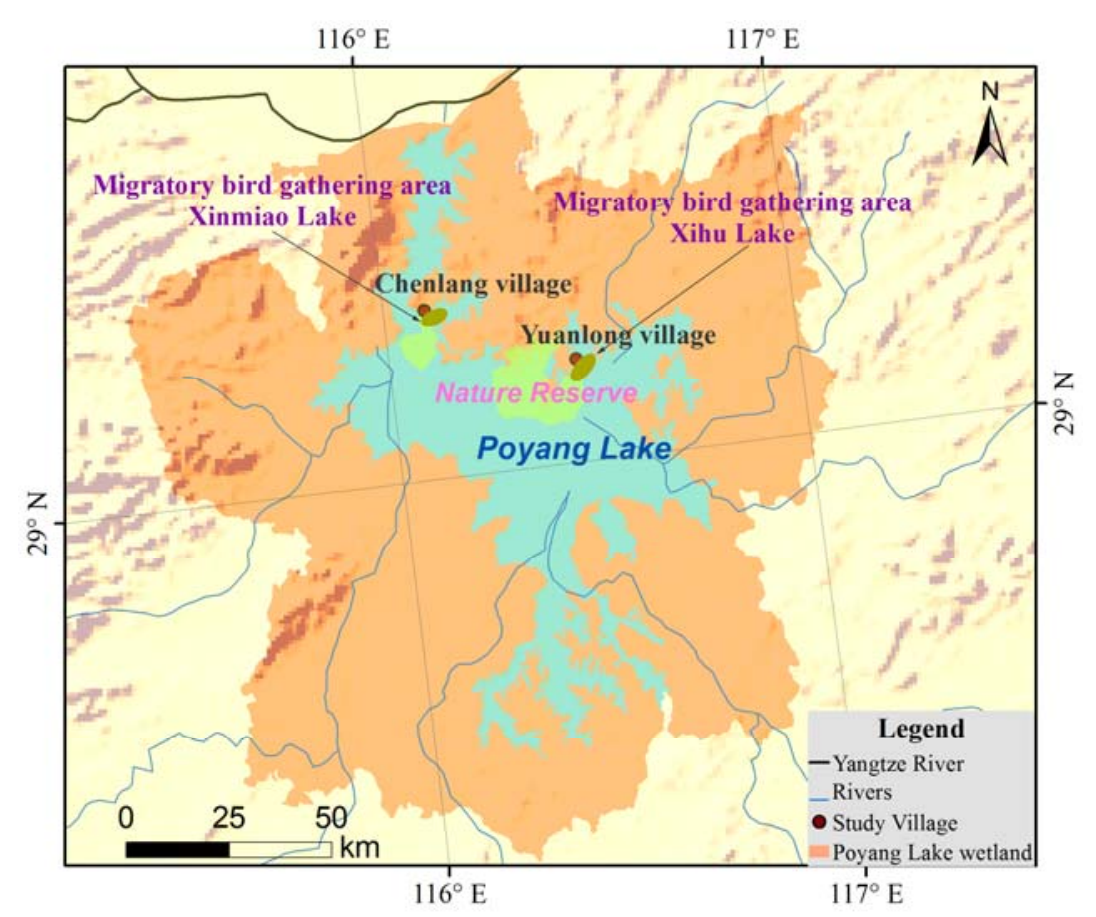

Figure 1 Geography of the study area.

biological diversity (Harris and Zhuang 2010). Poyang Lake has an abundance of aquatic and submerged plants that provide important food resources. Overwintering migratory birds were found in water areas, mudflats, herbaceous wetlands, and paddy fields in the wetlands of the central Yangtze River plain (Zhao 2002). Most overwintering migratory birds in Poyang Lake wetland were distributed in these areas and in shallow water that was less than $60 \mathrm{~cm}$ deep (Xia et al. 2010). Tens of thousands of migratory birds overwinter here every year ( $\mathrm{Li}$ et al. 2005), including $95 \%$ of the global population of the endangered oriental white stork (Ciconia boyciana), and $99 \%$ of the global population of the critically endangered Siberian crane. The Poyang Lake wetland is home to 310 species of birds, of which 16 are listed as threatened by the International Union for the Conservation of Nature (IUCN, www.iucnredlist.org).

We analyzed how ecological restoration and other human activities affect overwintering bird habitat in the Poyang Lake wetlands at a local level. We selected the villages of Chenlang and Yuanlong in Duchang County around Poyang Lake wetland as our wetland study sites. We chose these villages as representative examples of human activity in the Poyang Lake wetland because of 4 reasons: (1) The structure of land use/cover in the typical village was similar to the whole Poyang Lake wetland, and forest, cultivated land and wetland were the most important land use types of these areas, and its proportion were almost the same (Sun 2014). (2) The human activities were very typical and were widespread in the Poyang lake wetland, such as plantation, aquaculture, labor export and residence construction. (3) The habitat in and around the villages was an important part of the migratory bird gathering area, there were large numbers of dominant migratory birds in these villages, such as Tundra swan (Cygnus columbianus), greater white-fronted goose (Anser albifrons), Swan goose and Bean goose (Anser fabalis). (4) Governments were carrying out key ecological projects, such as the RFL and RFF projects, in these areas. We have defined the village according to the Chinese practice: a village includes both the built-up areas (e.g., residences, roads) and the surrounding land, usually within walking distance of the residences, in which the villagers work (e.g., cultivated fields, lake shores). Thus, much of the restoration work was performed within the boundaries of the village.

At the time, Chenlang village covered an area of $3.08 \mathrm{~km}^{2}$, and had a total population of 706 , made up of 160 families. The main economic activities were agriculture (cotton, rapeseed, rice), aquaculture and animal husbandry (fish, cattle, pigs), and the export of labor services. In 2000, the village implemented the RFL program in 23.3 ha of paddy fields that were threatened by flooding. One dike was removed, and water inflows during the rainy season have restored this area to herbaceous wetlands that provide suitable habitat for migratory birds. This new habitat is now connected to adjacent surviving areas of original habitat. The single-return RFL pattern was adopted in Chenlang, so none of the population moved elsewhere. In 2008, in order to improve their economic returns (especially from papermaking), the village planted fast-growing white poplar (Populus bonatii H. Lév.) 
in $71.7 \%$ of the 23.3 ha of the lake wetland that was restored under the RFL program. As of 2012, all of the trees were growing well, having reached a height of about $5 \mathrm{~m}$ after 4 years of growth, and the forested area was no longer a suitable habitat for migratory birds. Homes in the village were about $50 \mathrm{~m}$ from the nearest overwintering habitat for migratory birds. There were no RFF projects carried out near Chenlang because it has few areas of sloping cultivated land or barren land.

Yuanlong village covered an area of $2.72 \mathrm{~km}^{2}$ and had a total population of 2503, made up of 502 families. The main economic activities were agriculture (cotton, rapeseed, duzhong [Eucommia ulmoides] trees, rice), aquaculture and animal husbandry (cattle, pigs), and the export of labor services. In 2000, the village started implementing the RFL program. The double-return RFL pattern used by this village led to 980 people moving to higher ground, and 11.7 ha of flooded paddy fields and dry cultivated land were left uncultivated. Most of the paddy fields recovered into herbaceous wetlands that provided high-quality habitat for migratory birds. The dry cultivated land changed into grassland that was suitable for some kinds of migratory birds such as Grey heron (Ardea cinerea) and Swan goose (Anser cygnoides). The new habitats also connected with the surviving areas of original habitat. In $2008,42.8 \%$ of the RFL land was planted with fast-growing white poplar, but the survival rate of these trees was poor (about 10\%) because of a lack of management. Thus, this planting had little effect its suitability for migratory birds. In 2002, 4.2 ha of the slope dry cultivated land were planted with Eucommia bark (Cortex Eucommiae) trees in the RFF project; these trees are currently growing well, and have reached heights of 6 to $7 \mathrm{~m}$ after 10 years of growth. Homes in the village are only $20 \mathrm{~m}$ from the nearest overwintering habitat for migratory birds.

\subsection{Data source and analysis methods}

\subsubsection{The InVEST model}

The InVEST ecosystem services analysis model was developed by Stanford University in collaboration with other institutions in 2010, and it has since been widely used (e.g., Bai et al. 2011; Polasky et al. 2011). We used the model to quantify biodiversity and habitat quality based on land use and cover types. We assessed changes in the habitat quality for overwintering migratory birds by determining the changes in the size and spatial distribution of the different types of suitable habitat, and by incorporating the effects of threat factors (i.e., factors that threaten to decrease habitat suitability) based on the intensity and spatial distribution of human activities. The model considers four parameters, including habitat type, intensity of threat, distance between the habitat and the stressor, and the associated stress pathways (both linear and nonlinear), and habitat sensitivity (Tallis et al. 2013).

\subsubsection{Definition of suitable habitat for overwintering migratory birds}

We used SPOT 5 satellite remote-sensing images (2.5-m resolution) as a reference; the images were obtained from Google Earth on 6 June 2010, and we calculated the image resolution using known distances between objects in the images. We conducted field surveys in the two villages from 28 March to 15 April 2013. With the help of two experts from the migratory bird reserve and two villagers, we walked through all of the land of the two villages, and asked these experts to point out where migratory birds were foraging, breeding, and resting. We defined these areas as the habitats of the migratory birds. We traced the borders of these habitats on the SPOT images using natural borders such as pathways, dikes, and other divisions between adjacent land uses. We then asked our guides to identify the habitats that the migratory birds used 12 years earlier (in 2000), and sketched this habitat map on another SPOT image. We then invited 10 villagers who had lived in the village for at least 10 years to discuss and modify the habitat borders. To do so, we placed the habitat map that we had sketched on the remote-sensing image on a table, then asked the invited villagers to discuss the borders of the foraging, breeding, and resting places of the migratory birds. After about 1.5 hours of discussion, we reached consensus and sketched out a final map of habitats around the village. We then scanned the habitat map for use in ArcGIS (http://www.esri.com/products) and converted it into the grid format required by InVEST. We used the same method that produced the habitat maps, to visually interpret the land use and cover types in 
and near the two villages. We classified the land use and cover types based on the Chinese secondary classification system for ecosystems (Sun 2005).

Different types of water bird habitat differed in habitat suitability, and we quantified their relative suitability on a scale of $0-1$, with higher values indicating higher suitability. Generally, we assigned values based on our perceptions of the habitat suitability gained from our field surveys or annual migratory bird observation data. For example, our field surveys and discussions with villagers suggested that the shallow lakes, mudflats, marshes, herbaceous wetlands, and natural ponds were the most important gathering areas for the migratory birds (Appendix 1), so we defined their habitat suitability as 1. Grey heron, Chinese spotbilled duck (Anas zonorhyncha), Ruddy shelduck (Tadorna ferruginea) infrequently searched for food in paddy fields around the natural wetlands at the periphery of the study villages. The average number of cranes, herons, and geese amounted to nearly $25 \%$ of the total number of migratory birds in the remainder of our observation area (Sun 2014), so we assigned a habitat suitability value of 0.25 to these paddy fields. In the same way as the paddy field value was assigned, habitat suitability value of grassland, sparse shrubs in the study village was assigned as 0.3 and 0.1 respectively.

\subsubsection{Definition of relative threat parameters}

Human activities can be included as land use activities. Human activities that impact migratory birds are classified in the InVEST model as activities related to roads, residential activities, and agricultural production. In the land-use maps that we created during our field surveys, we classified human activities as transportation activities (including on paved and unpaved roads), residential activities (on residential land), cultivated activities (both on dry cultivated land and paddy field), and aquaculture (i.e., some aquaculture pond).

\subsubsection{Definition of threat intensity}

Each type of threat source has a different magnitude impact on migratory birds, and these degrees are called the threat intensity. In the InVEST model, as in the case of habitat suitability, the degrees were defined on a scale of $0-1$ with higher scores representing more intense stress. We defined the threat intensity scores using the Delphi method; that is, we asked 11 experts from the nature reserve's administration bureaus to rank them. Experts scored the threat intensity of each threat source, then we averaged these scores and asked the experts to review the results, and to reevaluate the scores if there was no consensus. We used the average score after the third round of scoring to represent the final threat intensity. The resulting intensities were 0.8 for residences, 0.6 for transportation land, 0.4 for cultivated land, and 0.3 for aquaculture ponds.

\subsubsection{Impact of the distance to the threat source}

Definition of threat source impact distance to habitat was obtained from the literature, InVEST model database and the observations of Poyang Lake wetland. Study by Sun (2014) showed that in Poyang Lake wetland $42.9 \%$ migrant workers worked or studied in cities throughout the year, but that they returned home in late December to celebrate the Chinese spring (new year) festival. During their visits, travel within the village and gatherings were more frequent, and the larger labor force performed activities that were potentially disruptive to waterfowl such as housing repairs. Thus, traffic and residential activities may have had a stronger impact at this time, particularly since migratory birds reach their maximum population size in the Poyang Lake region at that time, which coincides with the period of maximum human population and traffic in the villages. For our study, we chose a maximum impact distance of $200 \mathrm{~m}$ (Carney and Sydeman 1999) for paved roads and a minimum impact distance of $100 \mathrm{~m}$ for unpaved rural roads because in Poyang Lake wetland, paved roads had most transportation activities and the unpaved roads service as branch roads and had much less transportation activities. The InVEST model defines residences as having twice the impact of traffic on habitats for living organisms (Tallis et al. 2013); thus, we set a 400-m impact range for the rural residents and used this as a buffer for the maximum distance of the threats from the habitats. Agricultural land had an impact range that was similar to road traffic, but in winter, agricultural 
impact activities were minimal. We therefore defined the impact range for agricultural land (including cultivated land and aquaculture) as 100 m.

\subsubsection{Definition of habitat sensitivity to threat sources}

In the InVEST model, habitat sensitivity is defined for each combination of habitat and threat source, with values defined in the interval $[0,1]$ and higher scores representing greater sensitivity. Again, we used the Delphi method with the same 11 experts from the nature reserve's administration bureau, with three rounds of scoring. The results suggested that habitats were more sensitive to residential activities and paved roads, with a sensitivity value greater than o.4. The habitats were less sensitive to agricultural land (cultivated land and aquaculture ponds), with the sensitivity value less than 0.3 .

\section{Results and Discussions}

\subsection{Changes in habitat size}

The results show (Figure 2 and Table 1) that the habitat areas with low suitability value decreased, while the habitat area with high suitability value increased between 2000 and 2012 . To be specific, sparse shrubs (suitability value $=0.1$ ) in Chenlang village decreased by 0.7 ha because fields had been occupied for construction use. At the same time, its paddy field (suitability value $=0.25$ ) decreased by 78.7 ha because the paddy field had been changed into dry cultivated land; fishponds had been built on the paddy field; farmland had been returned to lake and the paddy field had been left uncultivated. Each covered areas of 34.7 ha, 15.0 ha, 23.3 ha (including 16.7 ha paddy field planted with poplar) and 4.9 ha respectively. Mud swamp and herbaceous wetlands (suitability value $=1.0$ ) increased by $9.7 \mathrm{ha}$, in which 4.9 ha came from paddy field discounting, 6.6 ha came from RFL, and 2.6 ha had been occupied for aquaculture.

In Yuanlong village, paddy field (suitability value $=0.25$ ) decreased by 8.4 ha, which included 1.3 ha paddy field which had been changed into dry cultivated land, 2.5 ha RFL and 4.6 ha discounting.
Mud swamp and herbaceous wetlands (suitability value $=0.8-1.0$ ) increased by 11.3 ha, in which 5.0 ha came from RFL and 6.3 ha from paddy field discounting. In the south-east of the village, a 3.2 ha dry cultivated land around the lake area has been restored into grassland in the RFL project. This area was also a habitat for migratory birds and its suitability value was 0.3 .

\subsection{Threat source changes}

Whether or not habitat can be affected by a threats source depended on the distance between them. If it exceeds a certain distance, the threats source can hardly have an impact on habitat. In this paper, we use $400 \mathrm{~m}$ (the maximum influential distance for migratory bird habitat) as the buffer distance to shape the buffer area of the habitat in the year of 2000. Results show that there was large scale threat decrease from 2000 to 2012 (Figure 3, Table 1), which included 38.1 ha (24.0\%) in Chenlang village and 33.0 ha (38.0\%) in Yuanlong village. Details were as follows:

From 2000 to 2012 Chenlang's aquaculture farm (threat weight $=0.3$ ) increased from o to 19.2 ha within the buffer area, which occupied 16.5 ha of paddy field (including 15.0 ha of habitat) and 2.7 ha of mud flats (including 2.6 ha of habitat). Dry cultivated land (threat weight $=0.4$ ) increased by 41.5 ha, which included a 52.3 ha increase from changing paddy field to cultivated land, a 7.6 ha decrease from cultivated discounting, orchard planning and housing occupied 2.8 and 0.3 ha of dry cultivated land respectively. Paddy field (threat weight $=0.4$ ) decreased by 99.8 ha, which included 7.0 ha discounting, 23.3 ha RFL, 52.3 ha from changed dry cultivated, 0.7 ha paddy file which was occupied by house building and 16.5 ha which was occupied by aquaculture farm buildings. Residential land (threat weight $=0.8$ ) increased by 2 ha, which occupied forest land (0.9 ha), dry cultivated (0.4 ha) and paddy field (0.7 ha). The total area of paved road and unpaved road (threat weight $=0.6$ ) didn't have great changes.

From 2000 to 2012, Yuanlong's dry cultivated(threat weight $=0.4$ ) decreased by 12 ha within the buffer area, in which 5.5 ha was cultivated discounting, 4.2 ha was returning farmland to forest, 3.2 ha was returning farmland to lake, 0.3 ha was occupied by newly built houses, while paddy field 


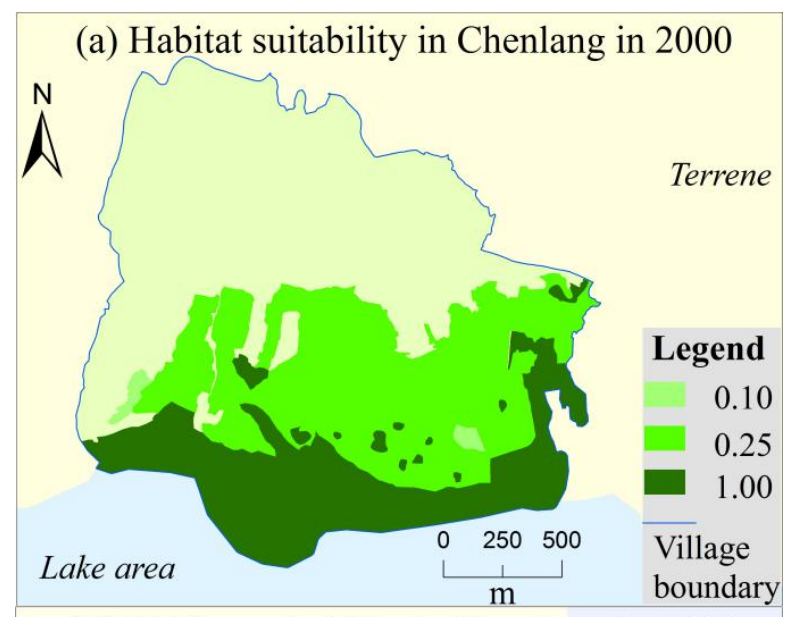

(C) Habitat suitability in Yuanlong in 2000

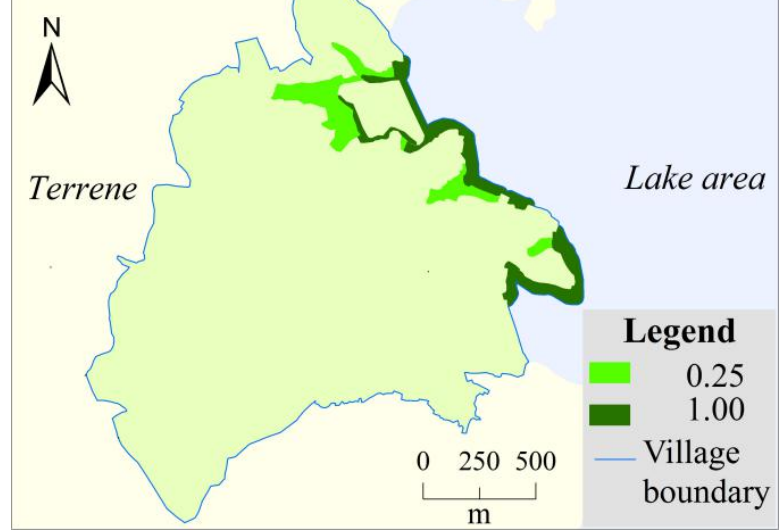

(b) Habitat suitability in Chenlang in 2012

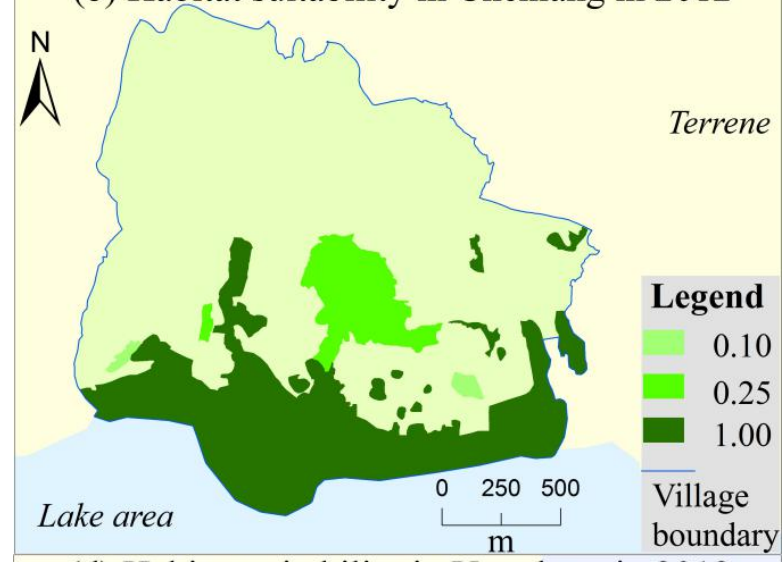

(d) Habitat suitability in Yuanlong in 2012

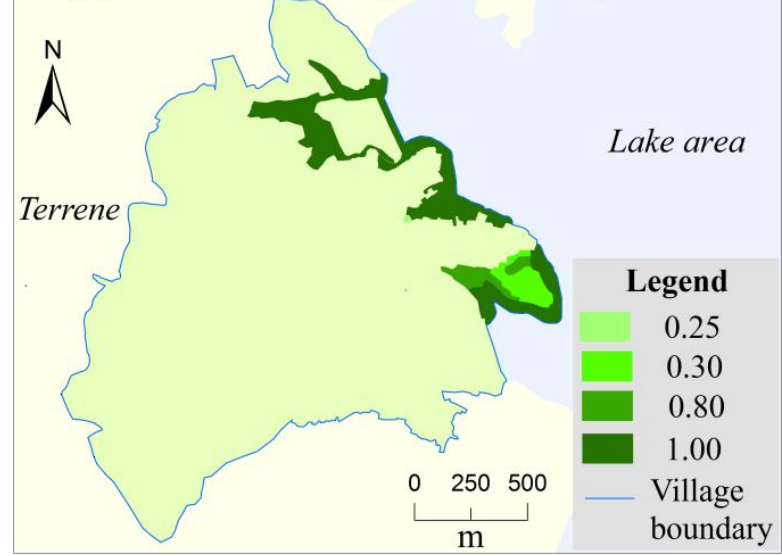

Figure 2 Habitat suitability distributions in 2000 and 2012 for the study villages.

Table 1 Features of changes in migratory bird habitat and threat source within $400 \mathrm{~m}$ buffer area

\begin{tabular}{|c|c|c|c|c|c|c|c|c|c|}
\hline \multirow[t]{2}{*}{ Habitat or threat types } & \multirow{2}{*}{$\begin{array}{l}\text { Value } \\
\text { assignment }\end{array}$} & \multicolumn{2}{|c|}{$\begin{array}{l}\text { Area in } \\
\text { Chenlang (ha) }\end{array}$} & \multicolumn{2}{|c|}{$\begin{array}{l}\text { Area in } \\
\text { Yuanlong (ha) }\end{array}$} & \multicolumn{2}{|c|}{$\begin{array}{l}\text { Area change in } \\
\text { Chenlang }\end{array}$} & \multicolumn{2}{|c|}{$\begin{array}{l}\text { Area change in } \\
\text { Yuanlong }\end{array}$} \\
\hline & & 2000 & 2012 & 2000 & 2012 & (ha) & (\%) & (ha) & (\%) \\
\hline Habitats & Suitability & & & & & & & & \\
\hline Sparse shrubs & 0.1 & 2.4 & 1.7 & 0.0 & 0.0 & -0.7 & -29.2 & 0.0 & -- \\
\hline Paddy field & 0.25 & 95.7 & 17.0 & 8.5 & 0.1 & -78.7 & -82.2 & -8.4 & -98.8 \\
\hline $\begin{array}{l}\text { Mud, swamp, herbaceous } \\
\text { wetlands }\end{array}$ & $0.8-1.0$ & 64.8 & 74.5 & $5 \cdot 4$ & 16.7 & 9.7 & 15.0 & 11.3 & 209.3 \\
\hline $\begin{array}{l}\text { Grassland from dry } \\
\text { cultivated land }\end{array}$ & 0.3 & o & o & o & 3.2 & o & & 3.2 & -- \\
\hline subtotal (ha) & & 162.9 & 93.2 & 13.9 & 19.9 & -69.7 & -42.8 & 6.0 & 43.2 \\
\hline Threats & Weight & & & & & & & & \\
\hline Aquaculture ponds & 0.3 & 0.0 & 18.2 & 19.7 & 19.7 & 18.2 & -- & 0.0 & 0.0 \\
\hline Dry cultivated land & 0.4 & 21.6 & 63.1 & 35.1 & 23.1 & 41.5 & 192.1 & -12 & -34.2 \\
\hline Paddy field & 0.4 & 129.8 & 30 & 19.3 & 2.2 & -99.8 & -76.9 & -17.1 & -88.6 \\
\hline Residential land & 0.8 & 6.2 & 8.2 & 11.9 & 8.0 & 2.0 & 32.3 & -3.9 & -32.8 \\
\hline Paved road & 0.6 & 0.0 & 0.5 & 0.0 & 0.1 & 0.5 & -- & 0.1 & -- \\
\hline Unpaved road & 0.6 & 1.2 & 0.7 & 0.8 & 0.7 & -0.5 & -41.7 & -0.1 & -12.5 \\
\hline Subtotal (ha) & & 158.8 & 120.7 & 86.8 & 53.8 & -38.1 & -24.0 & -33 & -38.0 \\
\hline $\begin{array}{l}\text { Not a threat, or being } \\
\text { habitat land }\end{array}$ & & 30.5 & 61.5 & 44.6 & 63.1 & 31.0 & 101.6 & 18.5 & 41.5 \\
\hline Total (ha) & & 258.4 & 258.4 & 136.8 & 136.8 & 0.0 & 0.0 & 0.0 & 0.0 \\
\hline
\end{tabular}


(a) Threat sources and land use and cover types

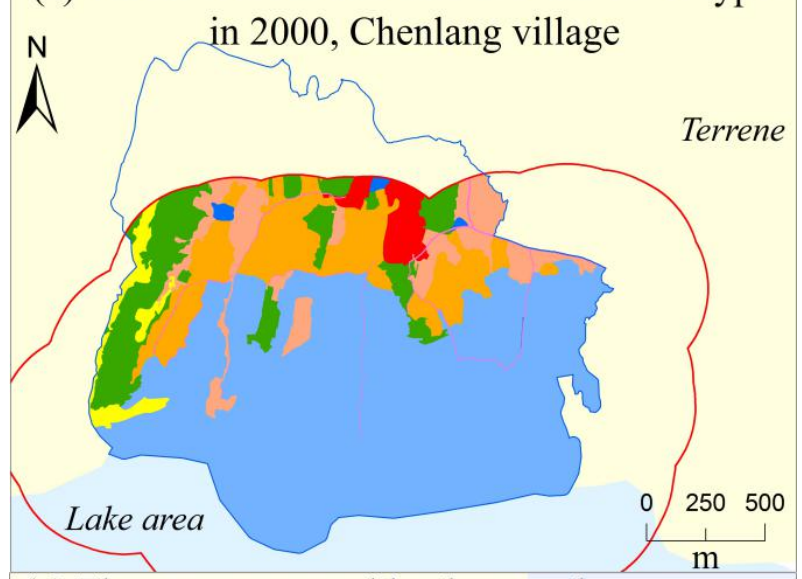

(c) Threat sources and land use and cover types

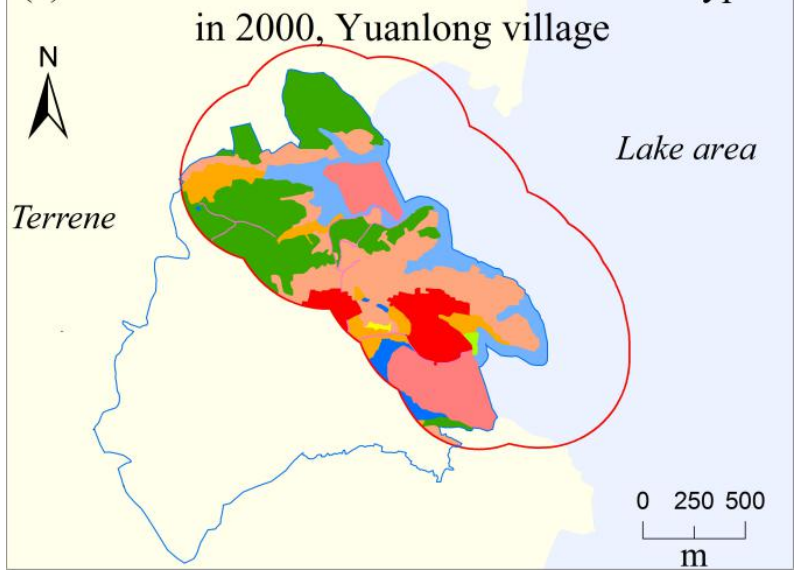

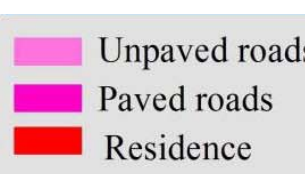

(b) Threat sources and land use and cover types

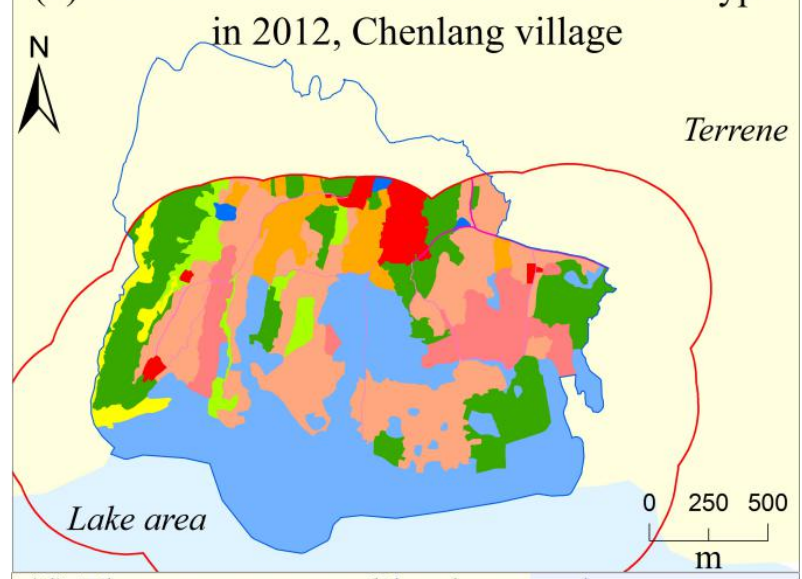

(d) Threat sources and land use and cover types
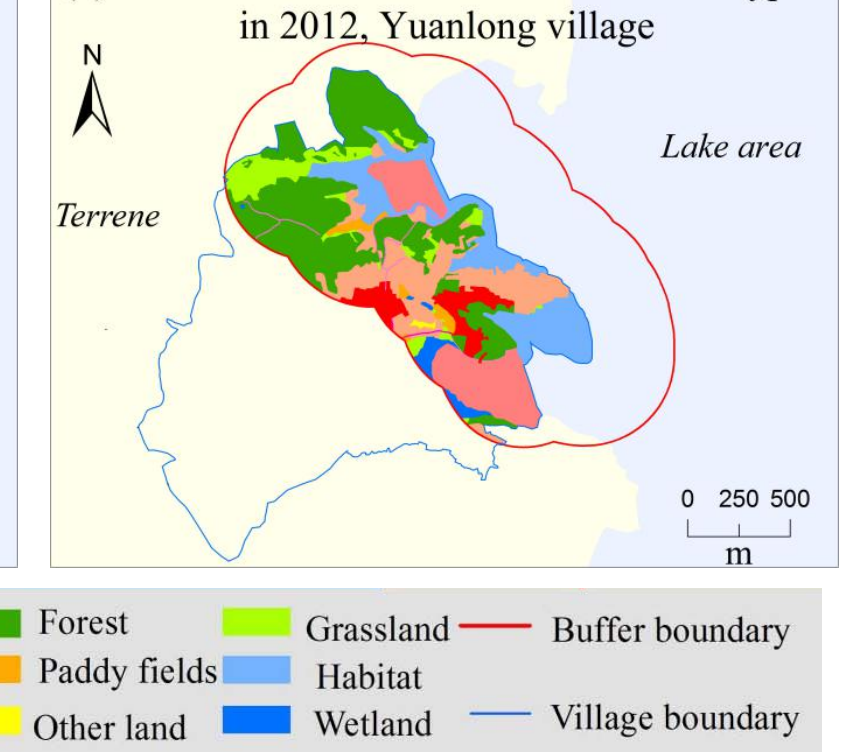

Figure 3 Threat source distribution and land-use and cover type characteristics in 2000 and 2012 for the two study villages. The red line represents a 400-m buffer based on the maximum distance of the threat source for residential activities.

been changed into dry cultivated made cultivated land increased by 1.3 ha. Paddy field (threat weight $=0.4$ ) decreased by 17.1 ha, in which 10.1 was discounting, 1.3 ha was changed into dry cultivated and 5.6 ha was RFL. Resident land (threat weight = o.8) had a net decrease of $3.8 \mathrm{ha}$, the main reason is the RFL project which refers to house removing. As a result, the houses in the south-east of the village which face flood threats moved to a high place beyond the buffer area, which decreased the residential area by 4.2 ha. However, there was 0.4 ha residence land increase during that period. Similarly, there was no big change in the total area of paved road and unpaved road.

\subsection{Changes in habitat quality}

In the InVEST model, the habitat quality is represented by using the value of $[0,1]$ and displayed by using habitat grid $(2.5 \mathrm{~m} \times 2.5 \mathrm{~m})$. By importing land use and cover data, habitat distribution data and the 4 parameters of the InVEST model, the InVEST model produced habitat quality maps for the study villages in 2000 and 2012 (Figure 4). Then by using grid value statistics, we got the average value of the grid, which was the average habitat quality of the map. The main impact factors that affected waterfowl habitat quality in our study villages are shown in Figure 5 . 


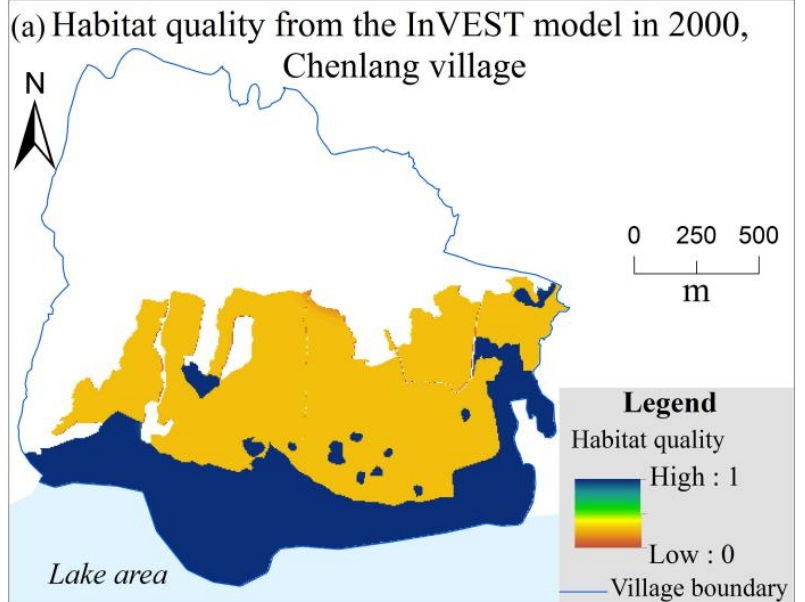

(c) Habitat quality from the InVEST model in 2000,

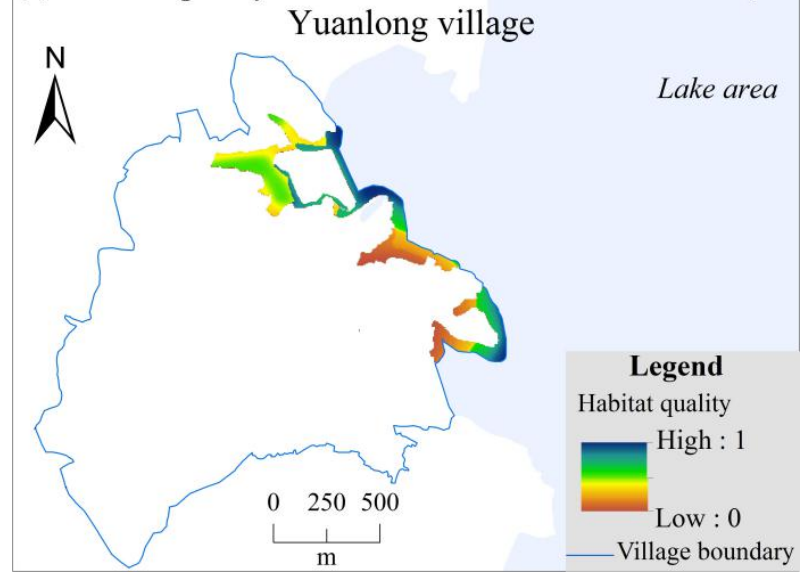

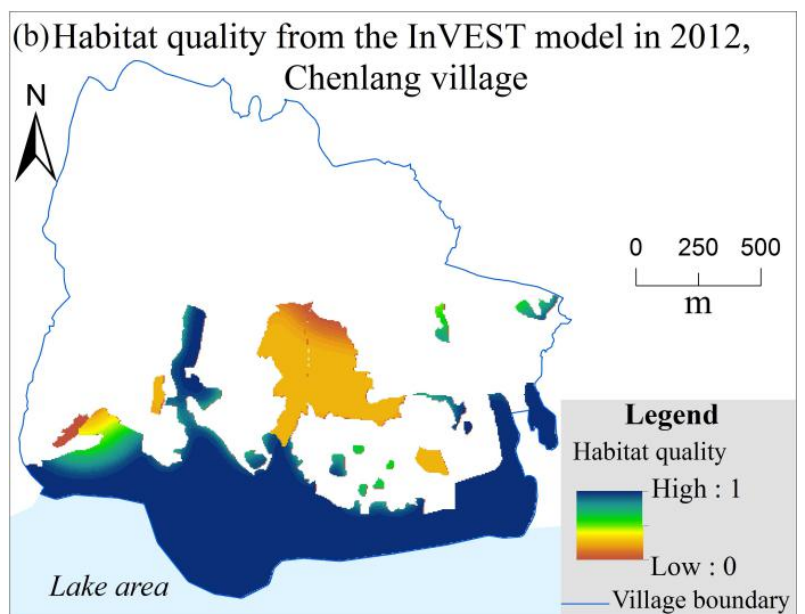

(d) Habitat quality from the InVEST model in 2012,

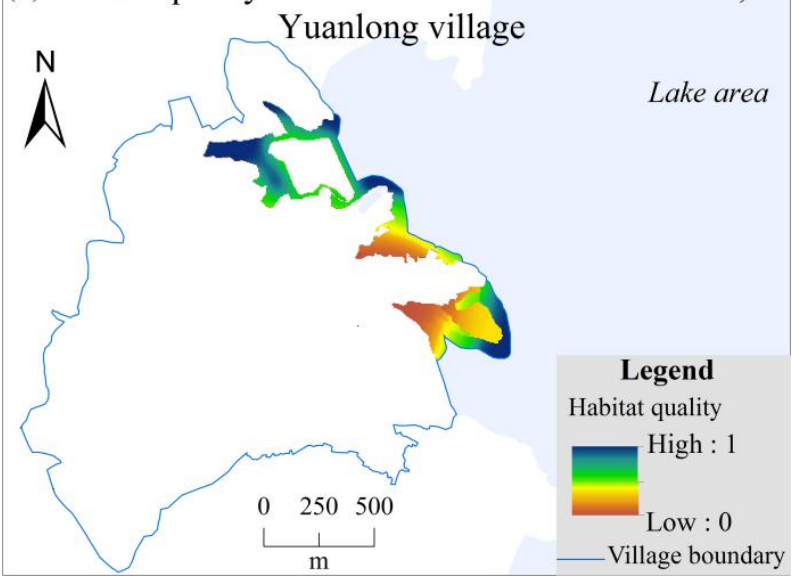

Figure 4 Habitat quality in 2000 and 2012 in and around the two study villages. Higher values mean more suitable habitats.

The model's calculations show that the average habitat quality in and around Chenlang in 2000 was 0.48 , which increased by $18.8 \%$ to 0.57 in 2012 . The reasons for these Changes can be analyzed from 4 parameters (habitat suitability, threat source, distance and sensitiveness) which have impacts on habitat quality: (1) It is known from the above analysis that low suitability habitat area decreased by 78.7 ha because paddy field had been changed into dry cultivated, aquaculture farm had been built on paddy field, RFL and paddy field discounting. Meanwhile, high suitability habitat area had an increase of 9.7 ha because of RFL and paddy field discounting. (2) Generally speaking, the area of threat intensity decline (42.8 ha) was far bigger than the area of threat intensity increase (4.7 ha). Among all types of main threats changes, paddy field being changed into dry cultivated didn't make vary, and paddy field being changed into aquaculture farm (fish pond) had a slight decrease.
Project RFL forced implement area to be changed to wetland or forest land (threat weight $=0$ ) and the threat intensity disappeared. However, the increase of the resident land use brought greater threat to the north part of the habitat. (3) Some human activities, such as planting poplar trees on wetland which was a part of RFL (paddy field turn to wetland then turn to forest, totally $16.7 \mathrm{ha}$ ) and cultivated land discounting exclusion (13.8 ha), all moved human cultivated activities further away from habitat. But at the same time, the newly built houses (2 ha) moved settlement activities closer to habitat. (4) There are various types of habitat sensitivity to threat source. The greater habitat sensitivity to a threat source, led to a larger impact of the threat source on habitat. Meanwhile, sensitivity attenuates when distance increases. In Chenlang village, except for a newly built 0.7 ha house (residence land) which is close to habitat, other changes of residence land and transportation 


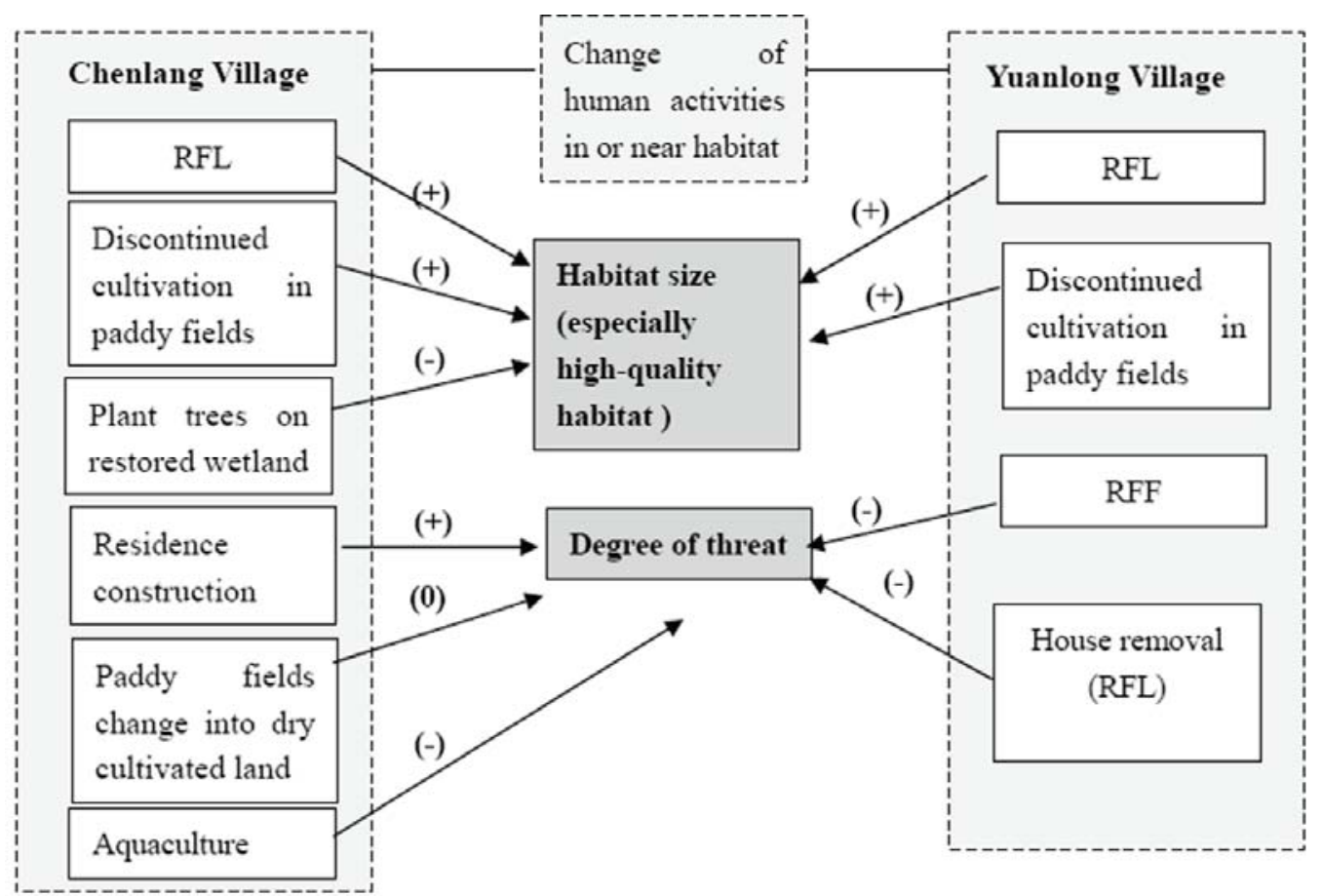

Figure 5 The main impact factors that affected waterfowl habitat quality in and near our study villages. Human activities increased (+) or decreased (-) or have no influence (o) on habitat size, the degree of threat to habitats, and habitat quality. Less important activities are not shown.

land maintain a certain distance from the habitat. The sensitivity of agriculture activities (cultivated, aquaculture etc.) is less than others, but change of agriculture activities such as RFL, cultivated discounting and paddy field being changed into dry cultivated is above $95 \%$ of the total change in human activities, and moreover, change of agriculture activities are around the habitat. Among the change of agriculture activities, RFL and cultivated discounting decrease threat intensity, and paddy field being changed into dry cultivated land or aquaculture land has little impact on nearby habitat.

For Yuanlong village, the InVEST calculations show that the average habitat quality increased from 0.44 in 2000 to 0.65 in 2012 (by 47.7\%). The reason for change also can also be analyzed from using the 4 parameters' impacts on habitat quality: (1) The area of habitat with suitability value which is above 0.8 increased by 11.3 ha because of RFL and paddy field discounting. The area of habitat with suitability value which is below 0.3 decreased by 5.2 ha. (2) For the reason of RFL, RFF and cultivated discounting, cultivated land (threat weight $=0.4$, including paddy field and dry cultivated) had a net decrease of 29.1 ha by $53.5 \%$, agriculture activities were consequently reduced obviously. House removal in the RFL project, resident land (threat weight $=0.8$ ) had a net decreas of 3.9 ha (32.6\%), which lead to obviously reduced settlement activities. (3) Cultivated discounting and project of RFF had made the distance between agriculture activities and habitat further than before, and removal of houses in the project of RFL had also made settlement activities further away than before. However, as the new habitat in the southeast is closer to the resident land, habitat in the southeast didn't increase obviously. (4) In the study range, the habitat scale increased and the threat source decreased. No matter what extent of sensitivity of habitat to threat source, habitat quality always increased.

\section{Conclusions and Discussions}

The above analysis shows that the ecological restoration project has played an important role in improving habitat quality. The main reason is that during the process of ecological restoration, a large area of land with artificial status such as agriculture land and residence land was changed 


\begin{tabular}{|c|c|c|c|c|c|}
\hline \multirow[b]{2}{*}{ Human activities } & \multirow[b]{2}{*}{ Main landuse change } & \multicolumn{3}{|c|}{ Impact on } & \multirow{2}{*}{$\begin{array}{l}\text { Habitat } \\
\text { sensitivity } \\
\text { to threat }\end{array}$} \\
\hline & & $\begin{array}{l}\text { Habitat } \\
\text { area }\end{array}$ & $\begin{array}{l}\text { Threat } \\
\text { intensity }\end{array}$ & $\begin{array}{l}\text { Threat } \\
\text { distance }\end{array}$ & \\
\hline \multicolumn{6}{|l|}{ 1. Ecological restoration } \\
\hline RFL (Single) & $\begin{array}{l}\text { Paddy field } \rightarrow \text { Herbaceous } \\
\text { wetlands or Shallow water }\end{array}$ & Increase & Decrease & Increase & Decrease \\
\hline RFL (Double) & $\begin{array}{l}\text { Paddy field } \rightarrow \text { Herbaceous } \\
\text { wetlands or Shallow water; }\end{array}$ & Increase & Decrease & Increase & Decrease \\
\hline RFF & $\begin{array}{l}\text { Residence } \rightarrow \text { Forest or Grass land } \\
\text { Dry cultivated land } \rightarrow \text { Forest }\end{array}$ & No impact & Decrease & Increase & Decrease \\
\hline \multicolumn{6}{|l|}{ 2. Other human activities } \\
\hline $\begin{array}{l}\text { Planting trees on } \\
\text { restored wetland }\end{array}$ & Herbaceous wetlands $\rightarrow$ Forest & Decrease & No impact & Increase & Increase \\
\hline $\begin{array}{l}\text { Paddy fields } \\
\text { discounting }\end{array}$ & $\begin{array}{l}\text { Paddy field } \rightarrow \text { Herbaceous } \\
\text { wetlands or grass land }\end{array}$ & Increase & Decrease & Increase & Decrease \\
\hline $\begin{array}{l}\text { Dry cultivated land } \\
\text { discounting }\end{array}$ & $\begin{array}{l}\text { Dry cultivated land } \rightarrow \text { Herbaceous } \\
\text { grass land }\end{array}$ & No impact & Decrease & Increase & Decrease \\
\hline Residence construction & $\begin{array}{l}\text { Agriculture land } \rightarrow \text { Construction } \\
\text { land }\end{array}$ & No impact & Increase & Decrease & Increase \\
\hline $\begin{array}{l}\text { Paddy fields change into } \\
\text { dry cultivated land }\end{array}$ & $\begin{array}{l}\text { Paddy fields } \rightarrow \text { Dry cultivated } \\
\text { land }\end{array}$ & No impact & No impact & No impact & No impact \\
\hline Aquaculture & Paddy fields $\rightarrow$ Aquaculture land & No impact & Decrease & No impact & Decrease \\
\hline
\end{tabular}

into land of natural status such as wetland, grass land and forest (Table 2), which increased habitat area, lowered the threat impact on habitat, reduced the distance between threat source and human activity area, and decreased the habitat sensibility to human activities.

For this specific ecological restoration project, the RFL (single) increased superior quality habitat and RFL (double) not only increased superior quality habitat, but also reduced settlement activities which have impact on habitat by removing housing. In addition, RFF projects which changed dry cultivated land into forest (duzhong, Eucommia ulmoides) had no impact on habitat area increase, but did increase the distance between agriculture activities and habitat, and indirect improving the habitat quality.

In the typical villages, there are many human activities, and they have complicated effects on migratory bird habitat (Table 2). As far as impact on habitat area is concerned, some paddy fields discounting around the lake area increasing the migratory bird habitat. Planting trees on restored wetland reduced the habitat derived from ecological restoration. Four other human activities almost have no influence on migratory bird habitat. As far as change of threats are concerned, excluding paddy fields and dry cultivated areas, and aquaculture decreased threat intensity while residence construction increased threat intensity, and the other 2 activities almost has no impact on threat intensify. As far as changes of distance between threat source and habitat are concerned, activities such as planting trees on restored wetland, paddy fields discounting, dry cultivated land discounting increased the distance between threat source and habitat and had positive impact on improving habitat quality, while residence construction shorten the distance and had negative impact on habitat quality, other activities almost has no impact on this distance. According to results from Delphi method with 11 experts from the nature reserve's administration bureau, different types of habitat had different sensitivity to threat sources. As to habitat sensitivity to threat, planting trees on restored wetland and residence construction had made habitat sensitivity to threat increase while paddy fields discounting, dry cultivated land discounting and aquaculture had made habitat sensitivity to threat decrease. Paddy fields change into dry cultivated land almost had no impact on habitat sensitivity to threat.

VanRees-Siewert and Dinsmore (1996) showed that if restoration efforts target only waterfowl, the restoration work will achieve good results within just a few years. Our research work 
also showed that even though the restoration work was not targeted at waterfowl and had not been implemented for a long time, the restoration engineering (and especially the RFL project) can improve habitats in the study sites. The management of wetland habitats to restore favorable characteristics can benefit habitats of diverse waterfowl species (Erwin and Beck 2007; O'Neal et al. 2008; Ma et al. 2010). Fang et al. (2006) also showed that the RFL project improved biodiversity in the Poyang Lake wetland, and that the populations of some overwintering migratory birds increased. The primary objective of the RFL project was to regulate floods, and it focused on hydrological restoration measures such as removing dikes that also increased the area of wetlands and improved the habitat quality for migratory birds. O'Neal et al. (2008) also found that successful hydrological restoration measures improved habitat quality and increased waterfowl populations. However, our study also shows that despite of restoration activities, change of many other human activities, such as discontinuing of cultivation, also has great contribution in improving the habitat. For example, paddy field discounting around the lake may increase superior habitat, and paddy field reducing can make

\section{References}

Bai Y, Zhuang CW, Ouyang ZY, et al. (2011) Spatial characteristics between biodiversity and ecosystem services in a human-dominated watershed. Ecological Complexity 8(2): 177-183. DOI: 10.1016/j.ecocom.2011.01.007.

Barter M, Chen L, Cao L, et al. (2004) Waterbird survey of the middle and lower Yangtze River floodplain in late January and early February 2004. China Forestry Publishing House, Beijing, China. (In Chinese)

Barzen J, Engels M, Burnham J, et al. (2009) Potential impact of a water control structure on the abundance and distribution of wintering waterbirds at Poyang Lake. International Crane Foundation, Baraboo, WI, USA. p 14.

Carney KM, Sydeman WJ (1999) A review of human disturbance effects on nesting colonial waterbirds. Waterbirds 22(1): 68-79. DOI: 10.2307/1521995.

Chen B, Cui P, Liu GH, et al. (2014) Relationships between changing water levels and numbers of wintering tuber-eating birds in Poyang Lake National Nature Reserve. Journal of Lake Sciences 26(2): 243-252. (In Chinese)

Cody ML (1985) Habitat Selection in Birds. Academic Press, Orlando, FL, USA. pp 1-559.

Erwin RM, Beck RA (2007) Restoration of waterbird habitats in Chesapeake Bay: great expectations or Sisyphus revisited? Waterbirds 30 (sp1): 163-76. DOI: 10.1675/1524-4695.

Fang JY, Wang ZH, Zhao SQ, et al. (2006) Biodiversity changes in the lakes of the Central Yangtze. Frontiers in Ecology and distance between habitat and agriculture activities larger and some to dry cultivated.

\section{Acknowledgements}

We are grateful for the financial support of the Asia-Pacific Network for Global Change Research project (reference number: ARCP2011-15NMYZhen), Technical Support Program of the Ministry of Science and Technology of China (No. 2013BACo3Bo4), and the Key Project for the Strategic Science Plan of the Institute of Geographic Sciences and Natural Resources Research of the Chinese Academy of Sciences (No. 2012ZDo07). We also thank the Science and Technology Bureau of Duchang County for their assistance during our field investigations and surveys. Finally, we are grateful to Denise Rennis, Geoff Hart, Bingzhen Du and Jinqi Liu for their assistance with the writing and revision of this paper.

\section{Electronic Supplementary Material:} Supplementary materials (Appendix 1) are available in the online version of this article at http://dx.doi.org./10.1007/s11629-014-3128-8.

the Environment 4(7): 369-377. DOI: 10.1890/1540-9295.

Harris J, Zhuang $\mathrm{H}$ (2010) An Ecosystem Approach to Resolving Conflicts Among Ecological and Economic Priorities for Poyang Lake Wetlands. IUCN report, Gland, Switzerland. pp 1-40.

Jiang LG, Yu XB, Zhao HX, et al. (2005) China's wetlands restoration around Poyang Lake, middle Yangtze: evidences from Landsat TM/ETM images. In: Proceedings of Geoscience and Remote Sensing Symposium, IGARSS'05 held in Seoul, Korea, 25-29 July 2005, IEEE International 4: 23872389. DOI: 10.1109/IGARSS.2005.1525458

Kwaiser K (2009) Accounting for observation uncertainty in species-habitat models: a case study using bird survey data from Poyang Lake, China. MSc thesis, University of Michigan, Ann Arbor, MI, USA, p 47.

Li F, Ji W. (2005) Crane Research in China--Aerial survey of Siberian cranes in the Poyang Lake Basin. Yunnan Educational Publishing House, Kunming, China. pp 58-65

Li F, Zhen L, Huang HQ, et al. (2009) Impacts of land-use functional change on WTA and economic compensation for core stakeholders: a case study in Poyang Lake. Resources Science 31(4): 580-589. (In Chinese)

Li H, Li CC, Zhang LH, et al. (2008) Relationship between water level and water area in Poyang Lake based on MODIS image. Quaternary Sciences 28(2): 332-337. (In Chinese)

Ma ZJ, Cai YT, Li B, et al. (2010) Managing wetland habitats for 
waterbirds: an international perspective. Wetlands 30(1): 1527. DOI 10.1007/s13157-009-0001-6

O’Neal BJ, Heske EJ, Stafford JD (2008) Waterbird response to wetlands restored through the conservation reserve enhancement program. Journal of Wildlife Management 72: 654-664. DOI: 10.2193/2007-165.

Polasky S, Nelson E, Pennington D, et al. (2011) The impact of land-use change on ecosystem services, biodiversity and returns to landowners: a case study in the State of Minnesota. Environmental and Resource Economics 48(2): 219-242. DOI: 10.1007/s10640-010-9407-0

Shankman D, Liang QL (2003) Landscape changes and increasing flood frequency in China's Poyang Lake region. The Professional Geographer 55(4): 434-445. DOI: 10.1111/ 0033-0124-5504003

Sun CZ (2014) InVEST Model based impact assessment of Land Use Change On Biodiversity and Soil Conservation functions in Poyang Lake Wetlands. PhD Thesis, Chinese Academy of Science, Beijing, China. p 57. (In Chinese)

Sun HL (2005) Ecosystem of China. Science Press, Beijing, China. (In Chinese)

Tallis HT, Ricketts T, Guerry AD, et al. (2013) InVEST 2.5.3 User's Guide. The Natural Capital Project, Stanford. pp 202-217.

VanRees-Siewert KL, Dinsmore JJ (1996) Influence of wetland age on bird use of restored wetlands in Iowa. Wetlands 16(4): 577-582. DOI: $10.1007 / \mathrm{BF} 03161348$

Wu GF, de Leeuw J, Skidmore AK, et al. (2009) Will the Three Gorges Dam affect the underwater light climate of Vallisneria spiralis L. and food habitat of Siberian crane in Poyang Lake? Hydrobiologia 623(1): 213-222. DOI: 10.1007/s10750-0089659-7

Xia SX, Yu XB, Fan N (2010) The wintering habitats of migratory birds and their relationship with water levels in Poyang Lake, China. Resources Science 32(11): 2072-2078. (In Chinese)
Yesou H, Li JR, Sylviane D, et al. (2009) Large inland lakes monitoring exploiting conjointly ENVISAT low and medium resolution image time series and alimetric data: case of Poyang and Dongting lakes (P.R. China) from 2000 to 2008 within DRAGON project. In: Proceedings of Earth observation and the water cycle held in Frascati, Italy, 18-20 November 2009, p 674.

Zhang ZW, Zheng GM (1999) Progress on the studies of habitatselection in birds. Chinese Zoology Society. Study of China Zoological Science. China Forestry Press, Beijing, China. pp 1099-110. (In Chinese)

Zhao SQ (2002) Study on land use changes, dynamics of waterfowl habitats, and some wintering characteristics of waterfowl in Dongting Lake area, Hunan Province. PhD Thesis, Peking University, Beijing, China.

Fraser LH, Keddy PA (2005) The world's largest wetlands: Ecology and conservation. Cambridge University Press, Cambridge, England.

Weber LM, Haig SM (1996) Shorebird use of south Carolina managed and natural coastal wetlands. Journal of Wildlife Management 60: 73-82.

Erwin RM (2002) Integrated management of waterbirds: beyond the conventional. Waterbirds 25(suppl. 2):5-12

Taft OW, Colwell MA, Isola CR, et al (2002) Waterbird responses to experimental drawdown: implications for multispecies management of wetland mosaics. Journal of Applied Ecology 39: 987-1001. DOI:10.1046/j.1365-2664. 2002.00763.x

Kaminski MR, Baldassarre GA, Pearse AT (2006) Waterbird responses to hydrological management of Wetlands Reserve Program habitats in New York. Wildlife Society Bulletin 34:921-926. DOI: 10.2193/o091-7648(2006)34

Bancroft GT, Gawlik DE, Rutchey K (2002) Distribution of wading birds relative to vegetation and water depths in the Northern Everglades of Florida, USA. Waterbirds 25: 265-277 